\title{
Households Inclination in Waste Separation Program
}

\author{
Azilah M.Akila, Foziah J. ${ }^{b}$, C.S Hoc \\ a\&cFaculty of Built Environment, Universiti Teknologi Malaysia \\ b Center for Innovative and Planning Development, \\ Universiti Teknologi Malaysia, 81310 Skudai, Johor Malaysia \\ aziazilah@gmail.com
}

\begin{abstract}
This paper examines the effect of socio-economic factors on recycling practices among households in Malaysia. Questionnaires were administered to 600 households in the newly emerging conurbation of Iskandar Malaysia Region. The results indicate that socio-economic variables have a significant effect on recycling activities. The results suggest that older people are more inclined to separate the households waste. The younger generation cited lack of time as the main reason for not recycling. The paper recommends several options to suit different households need to improve waste separation program. These include providing adequate infrastructures and raising environmental knowledge and values.
\end{abstract}

Keywords: household; waste separation; recycling behaviour; Iskandar Malaysia

eISSN: 2398-4279 @ 2017. The Authors. Published for AMER ABRA by e-International Publishing House, Ltd., UK. This is an open access article under the CC BY-NC-ND license (http://creativecommons.org/licenses/by-ncnd/4.0/). Peer-review under responsibility of AMER (Association of Malaysian Environment-Behaviour Researchers), ABRA (Association of Behavioural Researchers on Asians) and CE-Bs (Centre for EnvironmentBehaviour Studies), Faculty of Architecture, Planning \& Surveying, UniversitiTeknologi MARA, Malaysia.

https://doi.org/10.21834/ajqol.v2i6.43 


\subsection{Introduction}

Household solid waste (HSW) management is a major challenge in urban areas around the world. In this context, source separation is the key approach for minimizing waste, in turn, enhance recycling for disposal efficiency (Zhang, et. al.,2014). Source separation of waste refers to the collection of the different waste composition. The waste is first sorted at the place where it is generated and the fractions collected in separate containers. There is various source separation system. However, most systems rely on active, efficient and correct participation at the household level (Baltes et al., 2009; Leitol, 2014; Rada et al., 2013; Rousta et. al., 2015). The main body of source separation activity is the community resident. It is imperative to know what materials the community are willing to recycle, and what collection system would be more convenient to them or what economic instruments would result in sustainable recycling schemes. In Malaysia, most studies are centred on a general status of solid waste management (Moh. et. al., 2014). However, difficulties of a household in carrying out recycling activities are less studied. This study investigates the practice of waste separation among households and, whether demographic characteristics and the socio-economic factors influence recycling behaviour.

\section{Solid waste management in Malaysia}

In Malaysia, solid waste generation increased from 19,100 tonnes daily in 2006 to 33,000 tonnes daily in 2012 (Malaymail, 2014) which exceeded the projected generation of 30,000 tonnes by 2020 . Households waste is the main contributor to municipal solid waste (MSW). With more than $80 \%$ of the MSW comprised of recyclable materials, it is only logical that Malaysian carryout waste separation.

However, waste recycling is not a universal way of life in Malaysia (Omran et.al,2009). Public participation in the recycling program in Malaysia is very low. Malaysia targeted $22 \%$ of recycling rate by the year 2020, but the recycling rate was only $12.8 \%$ in 2015 (JPSPN, 2013). This rate is very much lower than the neighbouring countries. Singapore recorded a 60\% recycling rate in 2012 (NEA, 2013) and Philippines (Manila) from 28\% in 2006 (Antonio, 2010).

The Malaysian Government launched its first recycling program in 1993 followed by other campaigns ever since. Printed and electronic media on recycling were disseminated to educate and create awareness. However, these campaigns failed to motivate the community to respond positively. Awareness of recycling is high among Malaysians (82\%) but very few practise recycling for various reasons (Mutang \& Haron, 2012). Some citizens even look down on these efforts, implying that recycling is considered less important compared to other issues (Zain et al., 2012). Several studies stated that the reasons of Malaysian refuse to recycle is due to poor recycling facilities and inconvenient practice for them (Agamuthu, et.al, 2009).

In 2007, the Solid Waste and Public Cleansing Act was introduced to improve the current recycling rate of $5 \%$ to at least $22 \%$ by the year 2020 . In 2015 , the Malaysian 
government reiterated the waste separation program. This time, residents are expected to separate their household waste according to type i.e. paper, plastic and other recyclables before to waste disposal. Public acceptance and participation are, therefore, imperative to ensure the success of the program.

\subsection{Literature Review}

The complexity and diverse nature of recycling behaviour among households have attracted a lot of studies. Researchers have developed various models to explain factors that induced people to behave in an environmentally responsible manner. The Theory of Planned Behaviour (TPB) is broadly used as the model in the literature to explore pro-environmental behavior. The TPB (Ajzen, 1988) suggests that we can predict behaviour by asking people if they wish to behave in a particular manner (Jaarsma, 2012). From various studies on pro-environmental behaviour, three sets of variables appear to be persuasive in categorizing environmentally conscious individuals (Gilg et al., 2005). These centered around environmental and social values, socio-economic variables and psychological factors.

In Malaysia, Latif, et al., 2012) used the TPB model to identify environmental values and situational factors (Latif, et al., 2012) to predict recycling behavior. Attitudes on recycling and the belief about the importance of recycling are identified as predictors of recycling participation (John et. al, 2001). According to Tonglet et al., (2004) people can be persuaded to recycle if they have opportunities, facilities, and knowledge. We can enhance recycling practices if people are not deterred by the issues of physically recycling for example time, space and inconvenience. To achieve the recycling targets, the waste management problem should become an issue and responsibility of the local community rather than the local council waste services (Keramitsoglou.M.K et.al., 2013). Since the household is one of the main primary sources of municipal solid waste (Tariq and Mostafizur, 2007; Sujauddin et.al, 2008), it is only logical to examine household characteristics. This paper, therefore, needs to look closely at socio-economic and demographic variables as a starting point to support future actions and communication strategies to enhance people's involvement in recycling programmes in Malaysia.

\subsection{Methodology}

Iskandar Malaysia (IM) is the second development corridor located in Johor State that has been designated as one of the five economic growth areas in Malaysia. This region covers an area of 2217 square kilometers covering the city of Johor Bahru and the adjoining towns of Pontian, Senai, and Pasir Gudang. Modelled after the Pearl River Delta Economic Zone, IM is envisaged to capitalise on its current synergies with Singapore and the surrounding region. IM was also singled out as among the high-impact developments of the Ninth 
Malaysia Plan. The population is expected to increase to 3 million in the year 2025. IM was to be developed according to the Comprehensive Development Plan (CDP) formulated in 2006. The second comprehensive plan (CDP ii) was established in 2014 to provide the strategic framework to drive IM development for another ten years. CDPii encapsulated strategies and programs to ensure IM continue to be sustainable and resilient in the future. The key strategy is the Circle of Sustainability made up of wealth generation and wealth sharing, balanced by an optimal use of ecological assets, would enhance the Quality of Life in Iskandar Malaysia, turning it into a leading global region. Since IM seeks to adopt low carbon city initiatives (Ho et. al., 2013), it is highly critical that we promote proenvironmental behaviour among the communities.

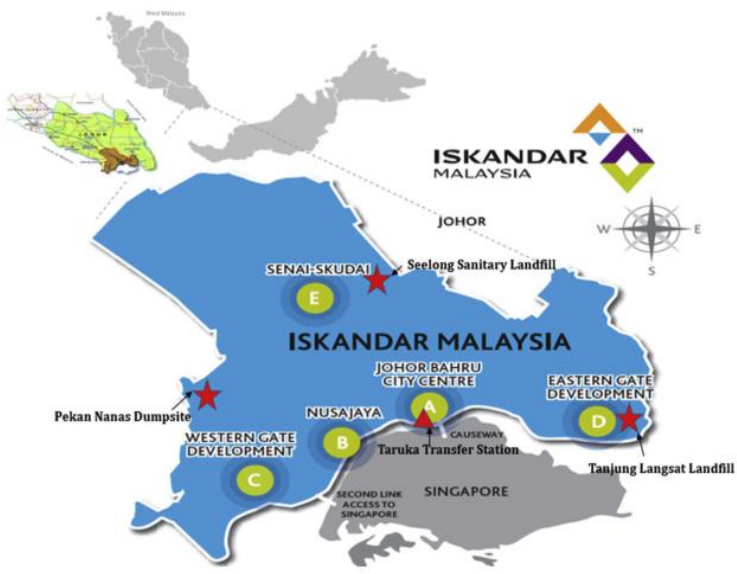

Figure 1: Flagships zones in Iskandar Malaysia and the current landfill sites.

Source: Ting, et.al. (2014)

\subsection{Survey and Questionnaire design}

A direct face to face survey was carried out among the households in selected neighbourhoods in Iskandar Malaysia. The survey questionnaire is made up of three sections a) respondent's profile; b) solid waste separation practices; and c) household options of improving solid waste management service. The options have four (4) attributes (Othman, 2002), i.e. the level of quality in term of collection frequency, separation of waste at source, disposal method and a monthly charge. 


\subsection{Results and Discussions}

\subsection{Profile of the respondents}

Table 1 reports the descriptive statistics of the main socio-economic characteristics of the respondents. The respondents are $55.6 \%$ men and $44.4 \%$ women. This proportion is similar to 2010 census of Malaysia. We categorized the age into three groups. Following Afroz, et.al. 2011, the study categorises age group 18-24 as the youngest group, the age group 25 to 34 as a middle age group and the age group over 35 as the older group. The average age was 41 years. More than $50 \%$ of the respondent are over 35 years old and categorized as older people. About $97.8 \%$ of the respondents had a formal education with $62.6 \%$ completed secondary education. Only $22.3 \%$ respondents obtained a higher education while $2.2 \%$ have no formal education.

\section{Table 1: Profile of respondents}

\begin{tabular}{lc}
\hline Age & $\%$ \\
\hline $18-24$ & 7.2 \\
$25-34$ & 24.7 \\
$35-44$ & 27.0 \\
$45-54$ & 22.9 \\
$55-64$ & 13.3 \\
65 and above & 4.8 \\
Total & 100.0 \\
Gender & $\%$ \\
Male & 55.6 \\
Female & 44.4 \\
Total & 100.0 \\
Education & $\%$ \\
Have not attended school & 2.2 \\
Primary school & 12.3 \\
Secondary school & 62.6 \\
Tertiary education & 22.8 \\
Total & 100.0 \\
Income Group & $\%$ \\
<RM1000 & 3.7 \\
RM1000-1499 & 5.2 \\
RM1500-1999 & 10.6 \\
RM2000-2499 & 16.1 \\
RM2500-2999 & 9.7 \\
RM3000-3999 & 24.3 \\
RM4000-4999 & 11.0 \\
RM5000 and above & 19.4 \\
Total & 100.0 \\
Homeownership & $\%$ \\
Own & 78.1 \\
Rent & 20.0 \\
Others & 2.0 \\
Total & 100.0 \\
\hline &
\end{tabular}




\subsection{Household solid waste management}

\subsubsection{Disposal method of household solid waste}

Currently, households place their waste bags in trash bins in front of their houses. The private collectors will collect the wastes twice or thrice a week. We asked the respondents, how and where they dispose of their household waste for each listed items.

Fig. 2 shows that recycling method varies according to types of material. The analysis on the method of recycling demonstrated two types of highly recycled material. Primary recyclable materials are glass, paper and old clothes i.e. $61.8 \%, 69 \%$ and $72.5 \%$ respectively. Other materials are aluminium (55.2\%), types of plastic (48.3\%). These materials are sold to door to door collectors. The door to door collection is done by private collectors or Non Governments Organization (NGOs) using various methods, for example, collection bins. They may also collect the material by lorry or van. The majority of the households dispose of their wastes such as polystyrene, plastics, and food waste into a waste bin without separation.

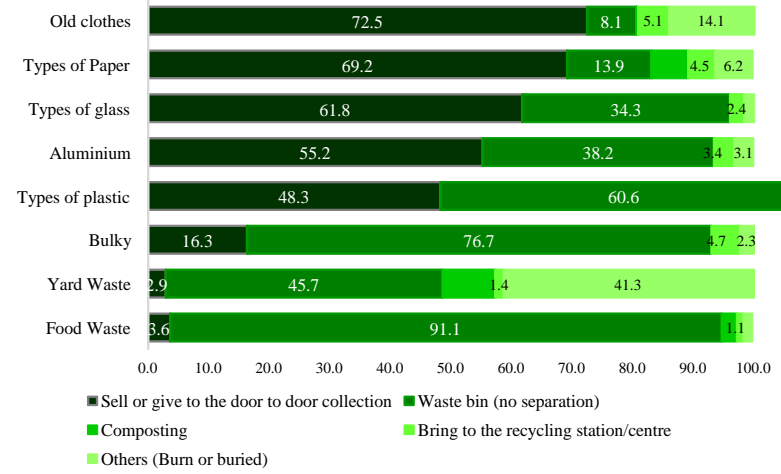

Figure 2 Disposal method by materials

\subsubsection{Solid waste separation practices}

The results reveal the majority of respondents $(37 \%)$ claimed that they were practicing waste separation according to the categories, but $26 \%$ never practiced. To be more specific, the figure shows $14 \%$ sometimes practiced; $12 \%$ practiced most of the time, and $11 \%$ seldom practiced separating solid waste. A positive relationship was found between age and frequency of recycling. People in the age group of 55 and above $(45 \%)$ are found to be more active in recycling compared to the younger ones (Fig. 3). Older individuals may be at a phase in their lives that is closer to retirement, or they may already retire, thus have more time devoted to recycling. Moreover, the responsibilities and time dedicated to caring for the children, if they continue to be a part of the family unit, are also less (Garcés, et.al, 2002). The study shows that waste separation practices among the younger age group (18- 
24 years old) are pretty discouraging.

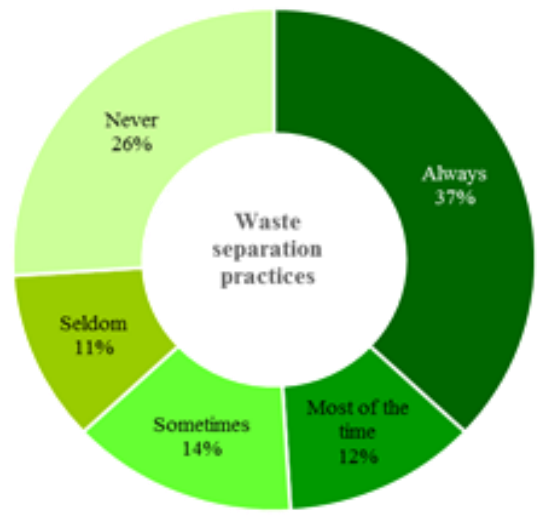

Figure 3: Frequency of solid waste separation

This is consistent with the findings from many other studies which also reveal that older households are more likely to participate in recycling activities (Singhirunnusorn, W. et.al, 2012; Bowman et.al, 1998; Meneses and Palacio, 2005; Saphores et al., 2006). However, this finding is contrary to the common expectation that younger people are likely to be more involved in recycling based on the assumption that they are more environmentally conscious.

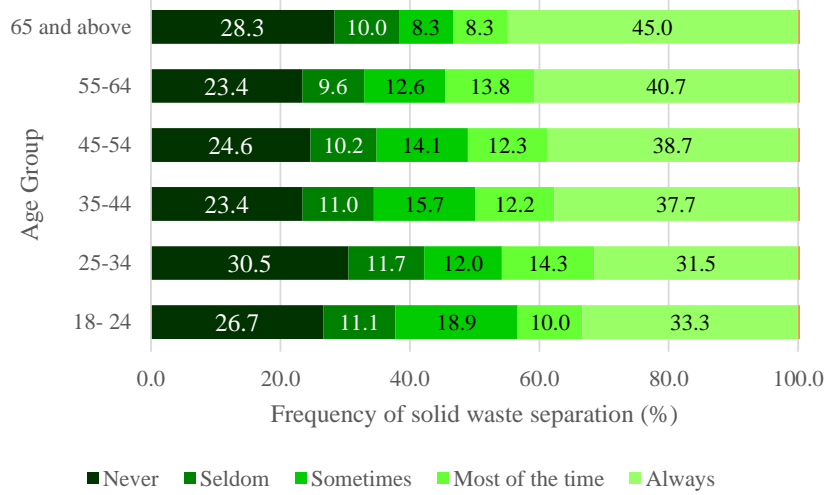

Figure 4 Frequency of solid waste separation by age group

Homeownership is found to be predictors of recycling activities (Oskamp et al., 1991). 
This factor can be explained by the fact that people who owned their houses tend to take better care of those homes. A peer pressure also caused residents especially those in affluent neighborhoods to behave with considerable regards to their neighbours. Thus, if one home recycles then other neighbors will likely do (Lockhart, 2003). Zen, et.al, (2014) and Vencatasawmy, et.al.,(2000) obtained a positive correlation between homeownership and recycling practices. In this study, people who owned their home $(38.5 \%)$ tend to recycle compared to people who rent their home or those living in company-owned houses. Such finding, however, does not concur with Mutang \& Haron, (2012), who found no relationship between home ownership and recycling practice.

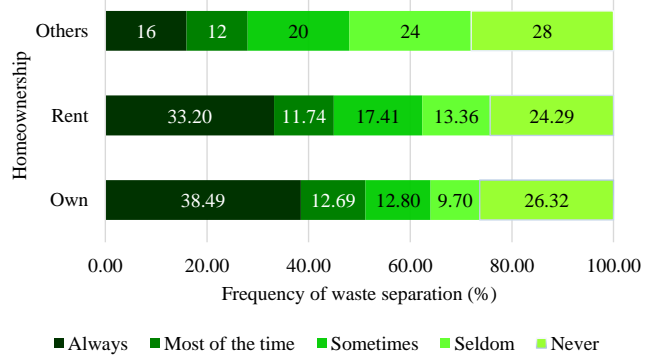

Figure 5: Frequency of solid waste separation by homeownership

\subsubsection{Enablers for willingness to participate in routine recycling activities}

The availability of an adequate recycling infrastructure that enables householders to recycle their waste is clearly a crucial part of any recycling programme. Nevertheless, there should be supporting factors to motivate householders to make use of that infrastructure (Martin, et.al, 2006). In this study, the response 'Yes, more likely' to participate was the highest $(80 \%)$ received in Iskandar Malaysia Region (Fig. 6).

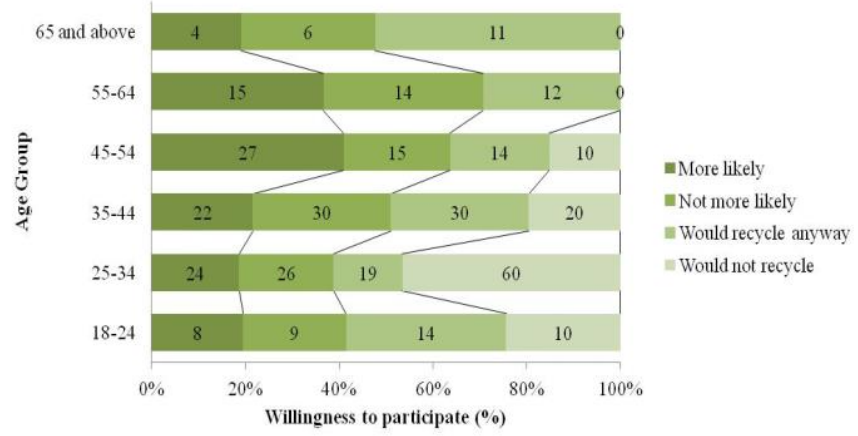

Figure 6: The willingness to participate in waste separation by age group 
The result indicates very encouraging feedback by respondent. However, the results show in Fig. 6 revealed those older age groups (45 to 64 years old) are more likely to participate in recycling activities. This concurs with the majority of studies that have similar findings where elderly households are more likely to recycle (Singhirunnusorn, W.et.al,2012; Bowman, $\mathrm{N}$ et.al.,1998). This implies that the elders are more willing to participate in recycling practices than the younger ones.

This research also seeks opinions on the best approach to increase recycling among the households. Although $24 \%$ of the respondents feel that the law should sanction recycling, the majority of respondents $(70 \%)$ will willingly participate without the legal sanction. Almost all the respondent ( $82 \%$ ) also agreed that they would more likely recycle if the municipality provides the facilities for waste separation at the curbside. Only $7 \%$ stated that they would recycle even if there are no such facilities.

\subsubsection{Household option of solid waste management services}

Respondents are also asked to select the level of quality of solid waste management. The majority of respondents choose high-quality services. This choice implies that most people are conscious of the need for proper waste management and its importance to the environment. This also indicates that the majority are ready to upgrade their waste separation practice. The option for high quality correlates positively with income level, i.e., people with higher income tend to choose a higher quality of services. People with higher income are also willing to pay a higher cost to obtain better quality services.

Table 2. Options of solid waste management services

\begin{tabular}{lll}
\hline & Low Quality & High Quality \\
\hline Collection Frequency & $\begin{array}{l}\text { Irregular three times } \\
\text { weekly }\end{array}$ & $\begin{array}{l}\text { Alternate day three times } \\
\text { weekly }\end{array}$ \\
\hline $\begin{array}{l}\text { Separation of waste at } \\
\text { source by households }\end{array}$ & $\begin{array}{l}\text { Separation at source } \\
\text { not needed }\end{array}$ & $\begin{array}{l}\text { Waste separation required } \\
\text { facilities and containers } \\
\text { provided free }\end{array}$ \\
\hline Disposal method & $\begin{array}{l}\text { Waste will be not } \\
\text { process }\end{array}$ & Waste will be processing \\
\hline Monthly charge & Average RM15 & RM25 \\
\hline
\end{tabular}

\subsection{Conclusion}

One of the consequences of rapid urbanization, industrialization and economic development in most developing countries is problems caused by solid waste generation. As land is scarce, landfill become less viable, making recycling not only sensible but essential. Although there is widespread public support for reducing and recycling of household waste, this is not reflected in participation levels in Iskandar Malaysia. 
A significant finding from the study indicates a positive relationship between socioeconomic and demographics factors such as age, home ownership and income with the frequency of recycling and options to improve solid waste management service. Homeownership is an important variable to predict willing recyclers. Older people also are found to be more active in recycling compared to the younger ones. Such finding is consistent with the conclusions from many other studies that also reveal that older households are more likely to participate in recycling activities. Thus, there is a need to encourage the youngsters to get interested and actively involved in the recycling activities. The findings further suggest that households are willing to pay a higher price for more frequent waste collection, waste disposal methods, and vehicle types.

This research extends our knowledge of household characteristics and their influence on environmental behaviour. It demonstrates that both households and local authorities need to play their part to achieve the environmental target. We recommend strategies namely environmental education, awareness campaigns, and the establishment of adequate collection systems. Such initiatives will improve the community-specific waste management programs. The authority also needs to incorporate waste management into the sustainable development agenda. It is also beneficial to the service provider since the majority of respondents agreed to spend more money to get high quality facilities as well as services.

\section{Acknowledgement}

The authors gratefully acknowledge the funding support for this work provided by Japan International Cooperation Agency (JICA) under the scheme of SATREPS Program (Science and Technology Research Partnership for Sustainable Development) for the project Development of Low Carbon Scenario for Asian Region and Research University Grant Program- Q.J130000.7121.03J01

\section{References}

Afroz, R., \& Masud, M. M. (2011). Using a contingent valuation approach for improved solid waste management facility: evidence from Kuala Lumpur, Malaysia. Waste Management (New York, N.Y.), 31(4), 800-8. Doi:10.1016/j.wasman.2010.10.028.

Agamuthu, P, SH Fauziah and K Khidzir (2009) Evolution of solid waste management in Malaysia: impacts and implications of the solid waste bill, 2007. Journal Material Cycles Waste Management Vol 11:96-10 3.Retrieve from Doi 10.1007/s10163-008-0231-3.

Ajzen, I. (1988). Attitudes, personality and behaviour. Milton Keynes: Open University Press.

gAntonio, L. C. (2010). Chapter 3 Study on Recyclables Collection Trends and Best Practices in the Philippines, (March), 40-70. 
Baltes, L., Draghici, C., Manea, C., Ceausescu, D., Tierean, M., 2009. Trends in selective collection of the household waste. Environ. Eng. Manage. J. 8 (4), 985- 991.

Bowman, N., Goodwin, J., Jones, P., \& Weaver, N. (1998). Sustaining recycling : identification and application of limiting factors in kerbside recycling areas. International Journal of Sustainable Development \& World Ecology, 5:4, p 263-276.

Garcés, C., Lafuente, A., Pedraja, M., \& Rivera, P. (2002). Urban waste recycling behavior: antecedents of participation in a selective collection program. Environmental Management, 30(3), 378-90. Doi:10.1007/s00267002-2601-2.

Gilg, A., Barr, S., \& Ford, N. (2005). Green consumption or sustainable lifestyles ? Identifying the sustainable consumer, 37, 481-504. http://doi.org/10.1016/j.futures.2004.10.016.

Ho Chin Siong, Yuzura Matsuoka, Simson, J., \& Gomi, K. (2013). Low carbon urban development strategy in Malaysia e The case of Iskandar Malaysia development corridor. Habitat International, 37, 43-51. http://doi.org/10.1016/j.habitatint.2011.12.018.

Jaarsma, a D. C. (2012). Nothing is as practical as a good theory. Perspectives on Medical Education, 1(3), 101-3. Doi:10.1007/s40037-012-0022-3.

John A. McCarty, L.J. Shrum (2001) The Influence of Individualism, Collectivism, and Locus of Control on Environmental Beliefs and Behavior. Journal of Public Policy \& Marketing: Spring 2001, Vol. 20, No. 1, pp. 93-104.

Keramitsoglou, K. M., \& Tsagarakis, K. P. (2013). Public participation in designing a recycling scheme towards maximum public acceptance. Resources, Conservation and Recycling, 70, 55-67. Doi:10.1016/j.resconrec.2012.09.015.

Latif, S. A., Omar, M. S., Bidin, Y. H., \& Awang, Z. (2012). Environmental Problems and Quality of Life: Situational Factor as a Predictor of Recycling Behaviour. Procedia - Social and Behavioral Sciences, 35, 682-688. Doi:10.1016/j.sbspro.2012.02.137.

Latif, S. A., Omar, M. S., Bidin, Y. H., \& Awang, Z. (2012). Environmental Values as a Predictor of Recycling Behaviour in Urban Areas: A Comparative Study. Procedia - Social and Behavioral Sciences, 50(July), 989-996. Doi:10.1016/j.sbspro.2012.08.100.

Leitol, C., 2014. Resource and cost efficient selective collection. Pollack Periodica 9 (Suppl. 1), 43-54.

Lockhart, S. M. (2003). Factors Affecting Participation in City Recycling Programs (Doctoral dissertation, Faculty of the Louisiana State University and Agricultural and Mechanical College in partial fulfillment of the requirements for the degree of Master of Science in The Department of Environmental Studies by Stacy M. Lockhart BS, Niagara University).

Low Carbon City 2025 -Sustainable Iskandar Malaysia.

Martin, M., Williams, I. D., \& Clark, M. (2006). Social, cultural and structural influences on household waste recycling: A case study. Resources, Conservation and Recycling, 48(4), 357-395. Doi:10.1016/j.resconrec.2005.09.005. 
Moh, Y. C., \& Abd Manaf, L. (2014). Overview of household solid waste recycling policy status and challenges in Malaysia. Resources, Conservation and Recycling, 82, 50-61. http://doi.org/10.1016/j.resconrec.2013.11.004.

Meneses GD, Palacio AB (2005). Recycling behavior: amultidimensional approach. Environ- ment and Behavior $\mathrm{x} ; 37: 837-60$.

Mutang, J., \& Haron, S. (2012). Factors predicting recycling behaviour among Malaysian. Southeast Asia Psychology Journal, 1, 68-80. Retrieved from http://www.cseap.edu.my/sapj/index.php/journal/singleJournal/8.

Malaymail Online (2014) Malaysians producing more solid waste than before.

Omran, A., Mahmood, A., Abdul Aziz, H., \& Robinson, G. M. (2009). Investigating households attitude toward recycling of solid waste in Malaysia: a case study. International Journal Of Environmental Research, 3(2), 275-288.

Othman, J. (2007). Economic Valuation Of Household Preference For Solid Waste Management In Malaysia: A Choice Modeling Approach, IJMS 14 (1), 189-212.

Rada, E.C., Ragazzi, M., Fedrizzi, P., 2013. Web-GIS oriented systems viability for municipal solid waste selective collection optimization in developed and transient economies. Waste Manage. 33 (4), 785-792.

Rousta, K., Bolton, K., Lundin, M., \& Dahlén, L. (2015). Quantitative assessment of distance to collection point and improved sorting information on source separation of household waste. Waste Management (New York, N.Y.), 40, 22-30. http://doi.org/10.1016/j.wasman.2015.03.005.

Saphores JM, Nixon H, Ogunseitan OA, Shapiro AA (2006). Household willingness to recycle electronic waste: an application to California. Environment and Behavior ;38:183-208.

Sujauddin, M., S.M.S. Huda and A.T.M.R. Hoque, (2008). Household solid waste characteristics and management in Chittagong, Bangladesh. Waste Manage., 28: 1688-1695.

Tariq Y, Mostafizur R.(2007) Monitoring quantity and characteristics of municipal solid waste in Dhaka city. Environmental Monitoring and Assessment;135: 3-11.

Tonglet, M., Phillips, P. S., \& Read, A. D. (2004). Using the Theory of Planned Behaviour to investigate the determinants of recycling behaviour: a case study from Brixworth, UK. Resources, Conservation and Recycling, 41(3), 191-214.

Vencatasawmy, C. P., Ohman, M., \& Brannstrom, T. (2000). A survey of recycling behaviour in households in Kiruna, Sweden. Waste Management \& Research, 18(6), 545-556. Doi:10.1177/0734242X0001800605.

Zain, S. M., Basri, N. E. A., Basri, H., Zakaria, N., Elfithri, R., Ahmad, M., Khan, I. A. I. (2012). Focusing on Recycling Practice to Promote Sustainable Behavior. Procedia - Social and Behavioral Sciences, 60, 546-555. Doi:10.1016/j.sbspro.2012.09.421.

Zen, I. S., Noor, Z. Z., \& Yusuf, R. O. (2014). The profiles of household solid waste recyclers and non-recyclers in Kuala Lumpur, Malaysia. Habitat International, 42, 83-89. Doi:10.1016/j.habitatint.2013.10.010.

Zhang, H., \& Wen, Z. (2014). Residents' Household Solid Waste (HSW) Source Separation Activity: A Case Study of Suzhou, China, 6446-6466. http://doi.org/10.3390/su6096446. 